This is nowhere more apparent than in northern Europe where Berg and Pravdin had named numerous forms from Karelia, although Himberg in a comprehensive review of the zoogeography of the North European coregonids in this volume reduced them to two only, one of which, Coregonus lavaretus, is represented by three "cryptic species". Himberg further considers that Europe was populated following the last glacial epoch by two ancestral forms which at that time were ecologically distinct, and have since given rise to many phenotypic populations, and hybridized extensively in isolated waters.

$\Lambda$ contribution which I found particularly interesting is that discussing the origin and distribution of Coregonus in the British Isles by Peter S. Maitland. There has been a similar confusion of nomenclature over the British populations, some fifteen in number, traditionally recognized as belonging to three species and eight subspecies found in lakes in Scotland, the Lake District, North Wales and Ireland. Maitland suggests that all could have originated from two (or three) sympatric species in a single post-glacial water body in the site of the present Irish Sea. The connexion between this western water mass and the central European one implied by Himberg's hypothesis has yet to be established. In the light of advances in taxonomy of the European forms it is disappointing to find Maitland still advocating the retention of Regan's scientific names for the British coregonids. This nomenclature has confused the relationships and affinities of these populations in the past, and was based on what by present day standards would be regarded as inadequate samples. Modern studies ${ }^{1}$ show that the British freshwater forms are referrablo to the two species widespread in Europe, Coregonus lavaretus and $C$. albula. ALWYNe Whegler

1 Wheeler, A., Fishes of the British Isles and North West Europe (Macmillan, London, 1969).

\section{SIEVE PLATES AND TUBES}

\section{The Phloem}

By Katherine Esau. (Encyclopaedia of Plant Anatomy. Second edition. Histology: Vol. 5, part 2.) Pp. ix +505 . (Gebrüder Borntraeger: Berlin and Stuttgart, 1969.) DM 188.

IT was almost inevitable, once the editors had decided to include a volume on the phloem in the "Handbuch der Pflanzenanatomie", that the task should be entrusted to Professor Katherine Esau, for she has established for herself a world reputation, not only as a plant anatomist, but specifically as a student of the phloem. This splendid volume is the outcome of three and a half years of work, interspersed, no doubt, with research of the same original and stimulating up-to-the-minute quality which one has eome to expect from her, and which shows no signs of falling off in either quality or quantity.

Professor Esau happily relates her treatment, on the one hand, to the place of the phloem in the life of the plant, and on the other to the historical development of our knowledge of the subject. Both these emphases are evidence of her breadth of sympathy, and both aro important in these days of narrow technology-orientated specialization, when knowledge of the natural world is too often valued morely in terms of the use we can make of it in the interests of physical existence. The historical note finds expression in a recall of the original occasions on which significant new ideas were put forward: "sieve plate", "slime", "nacré walls" all come alive in the words of their originators. This is a welcome feature.

In the systematic development of the subject, the sieve element naturally comes first in this book, and is given a thorough treatment (about one hundred pages). The elcetron microscope evidence is discussed fully as far as the summer of 1968. Esau herself has contributed very largely to this; and although, to single out one crucial point, she inclines to the view that the functioning sieve plate pores are "open", she is nevertheless very" fair to the opposite view. "There is hardly a feature in the sieve eloment that does not arouse some controversy," she remarks, with justice. Sieve tube physiology is not neglected.

Sections on parenchymatic elements and sclerenchymatic elements follow (about thirty pages), that on the companion cells being particularly full. Then, moving from histology to anatomy, there is a section on the distribution of the phloem in the plant body (twenty pages) and on its development as a mature system, the latter naturally lengthy (eighty pages) and including references to experimental work. Professor Esan has a well known interest in the phloic transmission of virus diseases. There is a section of ten pages on this, followed by a much longer section (100 pages) on comparative studies, which ranges from the larger brown algae and mosses to present-day angiosperms and the fossil record. This leads naturally to the discussion of phylogenetic trends, to which Esau devotes ten pages. Here, as with comparative studies, she acknowledges a great dearth of information.

Professor Esau concludes her great work with twenty pages attempting to relate structure to function. Here, few final conclusions are at present possible; but, as a physiologist, I was struck by the comprehensiveness of the author's grasp of a subject not her primary interest.

Needless to say, there is a large selection of first-rate figures and plates, about one hundred in the text and fifty in a terminal collection. These include many electron micrographs. There is a bibliography of more than a thousand references, and three indexes (author, plant and subject). The printing and paper are of high quality. This is clearly a book which every library must have, and which many rescarchers would wish to be able to afford. It will long remain a classic. D. C. Spanner

\section{PETROLOGICAL TOPICS}

\section{Mechanism of Igneous Intrusion}

Edited by G. Newall and N. Rast. (Geological Journal Special Tssue No. 2.) (Procecdings of a Symposium held in the University of Liverpool, January 9-11, 1969, under the auspices of Liverpool Geological Society.) Pp. 380. (Gallery: Liverpool, 1970.) 140s.

PRoviden the reader of this book does not expect a comprehensive, authoritative or even fully relevant series of articles on the subject of the mechanism of igneous intrusion, he will not be disappointed, for, judged as an array of petrological topies, both descriptive and theoretical, representative of current research and thinking, this is a useful and stimulating publication. It has the merit of bringing together ideas and conclusions stemming from radically difforent approaches; all of these must be reconciled in the formulation of coherent genetic theory. An attempt at such a synthesis is the subject of the final chapter by N. Rast, which owes much to records of the discussion at the symposium as well as to notions of his own. This, indeed, is an aspect of symposium reports, namely, the opportunity to express ideas in invited contributions that would doubtfully find place in the literature of standard journals. Correspondingly, however, the reader himself must recognize the need to exercise a critical appraisal of the contents.

Some of the contributions are essentially reviews. The first article, on igneous activity in orogenic cycles by E. K. Ustiyev, is appropriately of this nature and introduces the subject of the symposium on the broadest scale in terms of Earth history. A very relevant review, by W. S. Pitcher, is concerned with an assessment of the 